\title{
Internal Control Based on Pamali in Indigenous Peoples
}

\author{
$1^{\text {st }}$ Abin Suarsa \\ STIE Muhammadiyah Bandung \\ Universitas Muhammadiyah Bandung \\ Bandung, Indonesia \\ abinsuarsa@gmail.com
}

\author{
$2^{\text {nd }}$ Yeni Andriyani \\ STIE Muhammadiyah Bandung \\ Universitas Muhammadiyah Bandung \\ Bandung, Indonesia
}

\author{
$3^{\text {rd }}$ Ia Kurnia \\ STIE Muhammadiyah Bandung \\ Universitas Muhammadiyah Bandung \\ Bandung, Indonesia
}

\begin{abstract}
This research seeks to explore the Pamali culture (taboo) in indigenous peoples in Kampung Pulo, Garut, West Java as an internal control practice. Phenomenomology is used as a research method with traditional leaders (Pakuncen) and members of indigenous peoples as informants. This research found that there are five Pamali (Beating gongs is prohibited; Prohibited from making a prism-shaped roof; Four-legged animals are prohibited; Pilgrimageis prohibited on Wednesday; It is prohibited to add or subtract basic buildings) as internal control and life philosophy (simplicity, togetherness, loving nature, spirituality, and honesty). The informants applied five Pamali in their daily activities. Pakuncen always reminded the importance of complience to pamali. Fellow members of the community always remind each other. Regular meetings between members of indigenous peoples as a place to remind one another and solve problems. Pamali complience has an impact on the sustainability of indigenous peoples in Kampung Pulo.
\end{abstract}

Keywords-Internal Control Based, Pamali, Indigenous

\section{INTRODUCTION}

The sustainability of an organization is inseparable from the effectiveness of the internal control system owned by the organization [1]. The concept of sustainability is created from forestry science which means something that attempts to harvest more than the forest's ability to harvest under conditions normal [2]. The effectiveness of internal control will be achieved with integration of all parts of the organization including human resources [3]. Human error as part of human resources in an organization influences the effectiveness of the system internal control [4].

Preliminary surveys conducted by researchers provide an overview of how to control internally implemented by the Sundanese indigenous people, especially the adat community of Kampung Pulo so as to maintain customs for hundreds of years. Maintaining success These customs are inseparable from the internal control system which originates from a culture that is developing in a society created by involving the interaction of the elements of God, elements The environment, and the human element. The internal control system is packaged in a form the prohibitions named "Pamali". Aside from being a form of prohibitions, leave have philosophies of life in a balanced relationship with God, nature, and between humans to achieve their goals in the world and the hereafter.

\section{LITERATURE REVIEW}

Sensitive cultural problems always occur with regard to the community in research, as in the article [5]. The critical approach she undertook in research involved important issues concerning the study of indigenous peoples by outsiders, and the never-ending clashes in indigenous way of thingking and western ways of thinking. Defining the terminology, I will explain the use of the word indigenous as well because it is important for the whole research. When talking about indigenous people in general, I refer to the general practice of dealing with indigenous category [6].

Pamali is an intangible asset that is seen as a valuable asset in an organization includes acceptable values and norms that are reflected in interactions between individuals from the community [7]. Like the study of accounting by using social analysis (sociology) based on interpretive paradigms is an effort to bring accounting science closer to the cultural, religious and spiritual realities [7]. So in the study of management of internal control systems with cultural analysis seeks to bring management science to the same reality.

In modern business, the effectiveness of internal control is achieved when all interested parties in the organization have a reasonable guarantee that they understand the extent to which the entity's operational objectives are being achieved, financial statements are reliably published and compliance with applicable laws and regulations [8]. Internal control systems in indigenous peoples have the same goals as modern society namely to achieve the effectiveness of the rules set in the implementation so that it will achieve organizational goals. The difference between the two societies is:

- Orientation; material orientation becomes the main reference in modern society so ignoring qualitative values. Whereas in the traditional customs qualitative values are very stand out so as to form a sense of togetherness among members of the 
community.

- Rules; in modern societies the control system is in writing and in sequence, whereas in indigenous communities it is in the unwritten form

- In modern society rewards and punishments explicitly make reference in order uphold the obedience of its members, whereas in indigenous communities it emphasizes more on taste responsibility and respect for his ancestors and God

Internal control systems in indigenous peoples come from cultures that grow into values used as a basic foundation in behavior and way of life for humans to complete various problems in society. Culture is not just an art that grows deep society, but culture is used as a tool for sustaining life, it also contributes to continuity of the natural surroundings.

One culture that is of value in society is Taboo. Taboo, taboo, or prohibition is a very strong social prohibition on words, things or action. Violation of the taboo causes social sanctions against violators in the form of shame, disgrace, and other actions. Taboo in indigenous communities is used as internal internal control safeguard the order of indigenous peoples so as to guarantee its sustainability. In the community Pulo village customs, especially those that are part of the Sundanese community, are taboo with the term "Pamali".

Previous research on the village of Pulo included issues of care and maintenance wood and bamboo materials [9]. Likewise, calm research has been carried out ethnobotany of the indigenous communities of Kampung Pulo [10]. Approaching study a cultural approach has been carried out such as Islamic culture in the pulo village community [11]. Research on Pamali shows the inherent culture in life community in the pulo traditional community [12]. However from These studies are the main research in the context of cultural history, not yet touched aspects of the internal control system applied so that it plays a role in implementing compliance Pamali culture by indigenous people. While the study of internal control systems is more much to modern organizations. The purpose of this study is to understand the implementation of "Pamali" in everyday life. Research it also explores the effectiveness of "Pamali" which is obeyed by community members so that it supports its sustainability.

\section{RESEARCH METHOD}

In this study, the method used is a qualitative method. A qualitative method with a phenomenological approach which is a constructivist or naturalistic approach [13]. There are two fundamental reasons for the use of a qualitative approach in this study, namely: first, to explore and understand the meaning of the object of research from individuals or groups that are ascribed to social or humanitarian problems. Second, the acquisition of data can be more complete, more profound, and reliable, as well as all events in a social context that include feelings, norms, beliefs, habits, mental attitudes, and cultures adhered to by individuals and groups of individuals can be found [14].

Test Data credibility is done by triangulating the sources of interviews and through observation. And in the end a conclusion is drawn.

TABLE I. INFORMAN LIST

\begin{tabular}{|c|c|c|}
\hline No. & Informan & Information \\
\hline 1. & Mr. Umar & Deputy Pakuncen \\
\hline 2. & Mr. Zaki & Direct descendants \\
\hline 3. & Ms. Sri & Indigenous community member \\
\hline
\end{tabular}

\section{RESULT AND DISCUSSION}

A. Pamali As An Internal Control System

As an internal control system, Pamali in the society of Adat Pulo Village was made as a philosophy or basis or reference in carrying out activities. From the results of the study can be Pamali's position in the adat community is described as follows figures 1 .

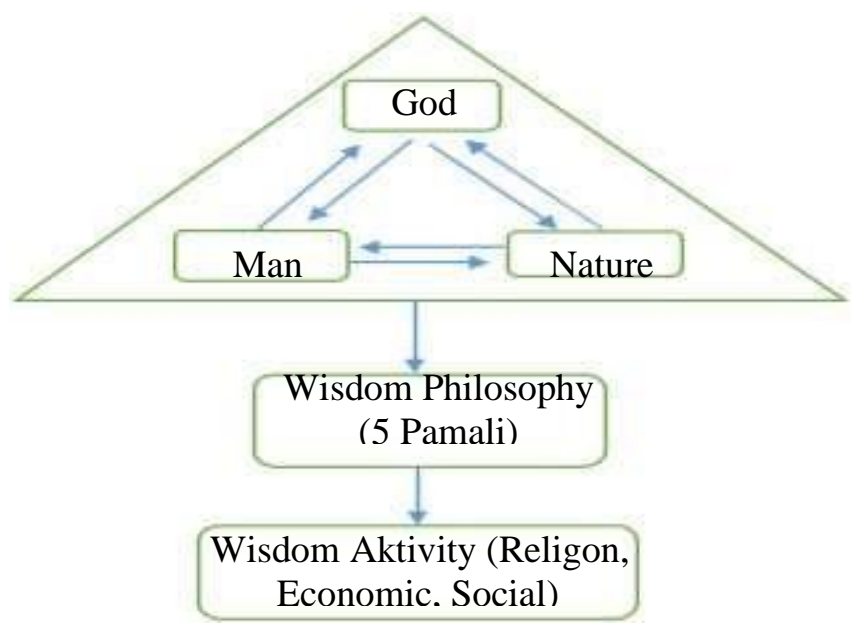

Fig. 1. Pamali Formation 
Underlying the formation of Pamali is the cycle of interaction between God, man and nature. Humans and nature are God's creations, both subject to God. Humans and nature are mutual interact and must respect each other, and take care. Underlying the formation of Pamali is the cycle of interaction between God, humans and nature.

Nature in the minds of the adat community of Pulo Village namely nature which is seen with all its creatures, and also nature which is not seen with all the creature.

Based on the relationship between God, humans, and nature, Pamali is formed to reflect environmental balance. Here are 5 Pamali in the Kampung Pulo Indigenous Peoples:

- Prohibition of striking a gong or goong; has the meaning that indigenous people Pulo village must always be in simplicity, in tenderness and avoid arrogance. Based on the results of interviews with informants $\mathrm{Mr}$. Umar and $\mathrm{Mr}$. Zaki said:

".... this prohibition arose when there was a celebration event in the context of circumcision of a boy from Arif Muhammad (Founder of Indigenous Village in Kampung Pulo). In the series of events, there was a crowd event by parading the children around the village. Accompaniment of the procession using a gamelan instrument, one of which is by beating a large gong. At the time of the event, there was a great wind that hit which caused the fall of Arif Muhammad's son to death. Since then, Arif Muhammad has banned members of the Pulo village community from beating big gongs...".

- Do not make jure / prism-shaped roofs; the meaning of jure / pisma gives individualist symbols, while the shape of the jolopong shows the string of togetherness within Public. So that the people of Kampung Pulo must unite, not be divorced and always divorced must protect one another's community members. Based on the results of interviews with informants Mr. Umar and Mr. Zaki said: “...just like exposure to pamali or forbidding hitting gongs, this prohibition stems from the circumcision event of a boy from Arif Muhammad. The procession was accompanied by the boy in a stretcher in the form of a jure I prism roof. So that the incident that led to the death of this child made a prohibition for the community that members of the indigenous community should not make a house with a roof in the form of a jure / prism, but it should be in the form of a longitudinal or elongated shape....".

- Not allowed to maintain quadrupeds; This prohibition gives meaning to that Pulo village community must love the environment and the natural surroundings. This means that Pulo village community must maintain the relationship between humans and nature alike as God's creatures who will provide balance and benefits for both, Mr. Zaki said:

"...our environment is small, so if we raise quadrupeds like cows it will pollute our environment...".

- No pilgrimages can be made on Wednesday; This prohibition relates to time management. Activities in a week do not have to always look for worldly relations, but also must looking for religion. This shows that Arif Muhammad taught a balance between the interests of the world and the hereafter, and the balance of human relations with God. The interview with the informant Mr. Umar illustrates that

"... the prohibition of pilgrimage on Wednesday begins with the Hindu community who always make pilgrimages to the Cangkuang temple located in Pulo village, to safeguard the faith of the Muslim community Arif Muhammad forbidding people to make pilgrimage on Wednesday, instead Islamic studies are held at the mosque ..."

- Not allowed to add or subtract basic buildings; Building face to face giving meaning that community members must pay attention to each other, help each other, and establish communication between communities so that hospitality is established between community members. The mosque on the west shows that members of the community are Muslim, and the position is Westernized shows that the Qibla is in the west. Prohibition of adding and subtracting buildings also means honesty. That the community must always act honestly in words and actions. Must always tell the truth, must not be added and must not be reduced. Mr. Umar and Mr. Zaki said:

"...the prohibition on adding and subtracting buildings also means honesty, the community must always act honestly in words and actions, it must always convey the truth, it must not be added and must not be reduced...."

Of the 5 Pamali, if described, can be interpreted as follows figures 2 . 


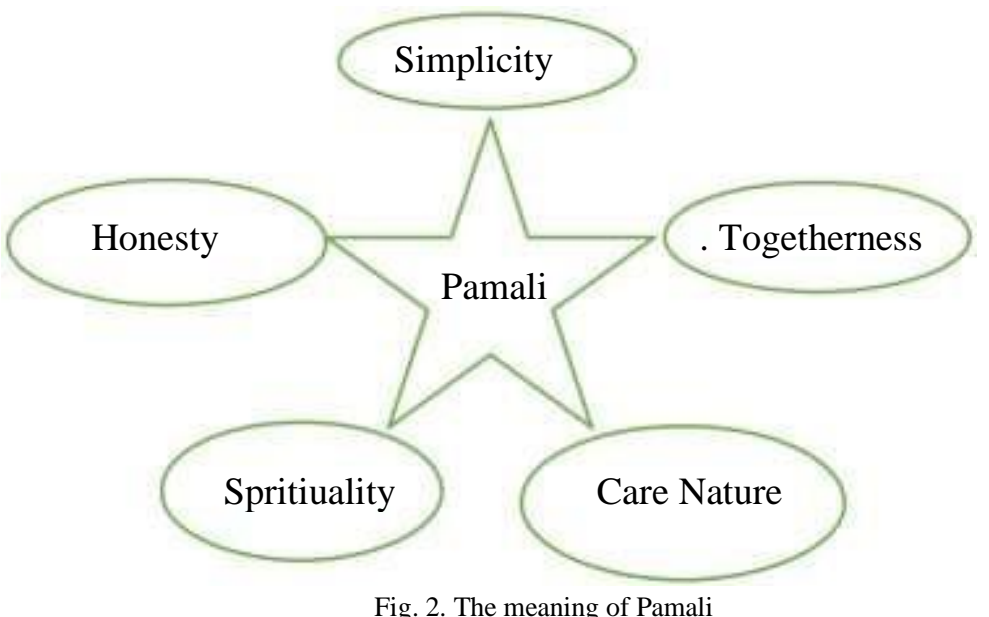

From Figure 2. Shows that the Pulo village adat community in social life mustuphold simplicity, togetherness, and honesty. His relationship with God as a form of obedience to its creator in the form of spirituality. Its relationship with the natural surroundings must be always protecting the environment from its sustainability.

Pamali will be reflected in everyday life. Every activity of the Pulo indigenous community always accompanied by ritual activities.

\section{B. Pamali Management in Implementation of Control}

To achieve the effectiveness of the Pamali implementation, so that all the pulo menta adat communities are all involved the rules are the implementation:

- The example of the adat leader. Exemplary is the main factor that gives community compliance with local wisdom owned. This is indicated by the behavior and lifestyle of the adat leader and the adat vice chair in his daily life, Ms. Sri said:

“....Mr. Pakuncen always set an example for us in his daily life... ".

- Communication. Communication will solve all problems faced by members Public. Communication between community members has sufficient intensity height of each activity of local wisdom, because every activity of local wisdom in it contains the philosophy of communication, Mr. Umar and Ms. Sri said:

"....we always communicate with members of the community, we always convey the problems encountered, and we provide mutual advice to solve problems...."

- Knowledge. Knowledge of local wisdom is conveyed informally. Involvement of all members of the community in every activity of wisdom, giving firsthand knowledge of local wisdom practices. This process gives awareness of the importance of local wisdom and gives a strong impression in the community, Mr. Umar said:

"....there is no formal learning about ritual procedures, we learn from experience, we know because we are obliged to attend every ritual, we always pay attention to every activity carried out by our traditional leader so we know everything.

- Remind each other. In the pulo village customary community there is no sanction formal, there are only social sanctions. Obedience to local wisdom is always done reminded by the customary leader or remind each other between members Public. The intensity of each other's reminders is quite high always delivered in loyal to local wisdom activities, Ms. Sri said:

"....remind each other members of the community is our obligation, so we do not violate established rules, we feel cared for by other community members..."

From the above governance styles, the obedience of the members of the pulo indigenous community can be relied upon so as to be able to maintain a culture that is its own characteristic.

\section{CONCLUSION}

From the results of the study, the following conclusions can be drawn:

- Pamali as a philosophy of life for indigenous peoples.

- As a philosophy of life, Pamali is used as an internal control system Public.

- Compliance with the effectiveness of the Pamalibased control system can be achieved in a way; the exemplary leader of adat, the intensity of communication, knowledge arises based on experience from activities, and always remind each other between members Public.

\section{ACKNOWLEDGMENTS}

We would like to thank the Directorate of Research and Community Service (DRPM), the Ministry of Research, Technology and Higher Education, Indonesia who has funded this research grant through a novice lecturer research scheme for the fiscal year 2019 


\section{REFERENCES}

[1] T. Aryati and L. R. Putrianti, "Pengaruh Pemanfaatan Teknologi Dan Modernisasi Sistem Administrasi Perpajakan Terhadap Kepatuhan Wajib Pajak Orang Pribadi," Jurnal Riset Akuntansi dan Keuangan, vol. 4, no. 3, 2016.

[2] T. Kuhlman and J. Farrington, "What is Sustainability?," Sustainability, vol. 2, no. 11, pp. 3436-3448, 2010.

[3] M. M. Vuitaiv, "Expanding Internal Control Functionality Scope," European Researcher, vol. 27, no. 8-2, pp. 1242-1247, 2012.

[4] E. K. Oseifuah and A. B. Gyekye, "Internal Control In Small And Microenterprises In The Vhembe District, Limpopo Province, South Africa," European Scientific Journal, vol. 9, no. 4, pp. 241251, 2013.

[5] S. T. Linda, Deconolizing Methodoligies, Research and Indigenous Peoples, Dunedin. New Zealand: University of Otago Press, 1999.

[6] R. Niezen, The origins of indigenism: Human rights and the politics of identity, Los Angeles. CA: University of California Press, 2003.

[7] N. Niswatin and M. Mahdalena, "Nilai Kearifan Lokal "Subak" Sebagai Modal Sosial Transmigran Etnis Bali," Jurnal Akuntansi Multiparadigma, vol. 7, no. 2, pp. 171-188, 2016.

[8] COSO, Committee of Sponsoring Organization of Treadway Commission Internal Control-Integrated Framework, New York: AICPA, 2010.

[9] A. Hidajat, F. Fatharani, D. Martika, F. Andika and G. Putih, "Kajian Penggunaan Material Kayu dan Bambu Ditinjau Dari Pengawetan dan Perawatan," Jurnal Rekakarsa, vol. 2, no. 4, pp. 110, 2014.

[10] N. Ramdianti, H. A. Hidayah and Y. Widiawati, "Kajian Etnobotani Mayarakat Adat Kampung Pulo di Kabupaten Garut," Majalah Ilmiah Biosfera, vol. 30, no. 1, pp. 38-50, 2013.

[11] A. Syukur, "KAMPUNG PULO: Traces of Islamic Culture in Garut Regency," SASDAYA: Gadjah Mada Journal of Humanities, vol. 1, no. 1, pp. 34-52, 2016.

[12] A. J. Rohaeni and W. Listiani, "Pamali Dalam Kebudayaan Masyarakat Adat Sunda," Jurnal Seni Rupa ATRAT, vol. 1, no. 2, pp. 10-17, 2013.

[13] L. Fauji, M. Sudarma and M. Achsin, "Penerapan Sistem Pengendalian Mutu dalam Meningkatkan Kualitas Audit," Jurnal Akuntansi Multiparadigma, vol. 6, no. 1, pp. 38-52, 2015.

[14] J. W. Creswell, Research Design: Pendekatan Kualitatif, Kuantitatif, dan Mixed, Yogyakarta: PT Pustaka Pelajar, 2015. 